\title{
The Urgency of Fatwa in The Law of Sharia Economics in Indonesia
}

\author{
Elsy Renie \\ State Institute for Islamic Studies (IAIN) of Batusangkar \\ e-mail: elsyrenie@iainbatusangkar.ac.id
}

\begin{tabular}{|l|l|l|}
\hline Received: 29-06-2021 & Revised: 29-11-2021 & Accepted: 29-11-2021 \\
\hline
\end{tabular}

Abstract: Fatwas of the National Sharia Council-Indonesian Ulama Council (DSN-MUI), in the field of sharia economics, has filled the legal vacuum related to the economic activities of the people. The increased of activity in the Mu'amalah area which is so fast requires a responsive fatwa. It can be seen from the rapid development of financial products for sharia financial institutions today. The legal strength of a fatwa is non-binding because it is not included in the constitution bierarchy in Indonesia which has caused debate for some people. But, several DSN-MUI fatwa have been transformed into part of national law, such as constitution No. 21 of 2008 concerning Banking, and some of which have also been absorbed into Bank. Indonesia regulations, Syari'ah Financial Services Authority Regulation (OJK). This paper tries to analyze the role of fatwas in filling the legal vacuum in the development of the shari'ah economy in Indonesia and how the fatwas of the DSN-MUI can be transformed into national law. The author concludes that the role of DSN-MUI as the only institution that issued a fatw a related to the activities of shari' ah financial institutions in Indonesia is very important in the area of national legal politics.

Abstrak: Fatwa Dewan Syariah Nasional-Majelis Ulama Indonesia (DSN-MUI), di bidang ekonomi syariah, telah mengisi kekosongan hukum terkait kegiatan ekonomi umat. Peningkatan aktivitas di wilayah Mu'amalah yang begitu pesat membutuhkan fatwa yang responsif. Hal ini terlihat dari pesatnya perkembangan produk keuangan lembaga keuangan syariah saat ini. Kekuatan hukum suatu fatwa tidak mengikat karena tidak termasuk dalam hierarki konstitusi di Indonesia yang menimbulkan perdebatan bagi sebagian kalangan. Namun, beberapa fatwa DSN-MUI telah menjadi bagian dari hukum nasional, seperti UU No 21 Tahun 2008 tentang Perbankan, dan beberapa di antaranya juga telah diserap ke dalam peraturan Bank Indonesia, Peraturan Otoritas Jasa Keuangan (OJK) Syari'ah. . Tulisan ini mencoba menganalisis peran fatwa dalam mengisi kekosongan hukum dalam perkembangan ekonomi syariah di Indonesia dan bagaimana fatwa DSN-MUI dapat ditransformasikan ke dalam hukum nasional. Penulis menyimpulkan bahwa peran DSN-MUI sebagai satu-satunya lembaga yang mengeluarkan fatwa terkait kegiatan lembaga keuangan syariah di Indonesia sangat penting dalam ranah politik hukum nasional.

Keywords: Fatwa, Sharia Ecomonis. DSN-MUI.

\section{INTRODUCTION}

$I$ slamic Economic Development in Indonesia is inseparable from the important role played by the National Sharia Council, which was deliberately formed by the Indonesian Ulama Council to develop and issue fatwas related to sharia economic problems. The presence of the DSN-MUI also accelerates the development of Islamic financial institutions in Indonesia.

Sharia-based economic development on the other hand, must be supported by good regulation. This will strengthen the existence of the Islamic economy in the constellation of legal 
politics in Indonesia. The important role of the DSN-MUI fatwas regarding Islamic economic activities has contributed significantly in filling the legal vacuum related to sharia-based economic activities.

So the question is; is it possible to use the DSN fatwa as a binding legal basis, considering the legal strength of a fatwa which is non-binding as it is not included in the constitution hierarchy in Indonesia as regulated in the Law No. 10 of 2004 concerning the establishment of legal constitution (Law No. 10 of 2004). However, based on the results of research produced by the National Legal Development Agency of the Ministry of Law and Human Rights, that the legal fatwa of DSN-MUI has binding legal powers for sharia economic actors both directly and indirectly.

\section{RESEARCH METHODS}

This paper tries to analyze the role of fatwas in filling the legal vacuum in the development of the shari'ah economy in Indonesia and how the fatwas of the DSNMUI can be transformed into national law. This Research is normative law Research by tracing any reference, fatwas, constitution are related to the focus of this Topic. The approach used in this research a statute approach to analyze various laws and regulations related to the issue of the position and material content of the DSNMUI fatwa. In addition, a conceptual approach is used to analyze and formulate the concept of the important role of fatwas in sharia economic activities in Indonesia

\section{RESULT AND DISCUSSION}

Fatwa in Developing a Sharia Economy
The fatwa (الفتوى) means the answer to an event. While the definition of fatwa according to syara' is to explain syara' law in a specific matter as an answer to a question, even though the person who asked was clearly identified or not, both individually and collectively (Qardhawi, 1997: 7). The definition of fatwa according to the Indonesian Dictionary (KBBI) is: (1) answers in the form of decisions or opinions given by experts about a problem and (2) advice from wise people, in the form of good lessons and advices. Fatwa is the official answer to questions and problems concerning sharia legal issues. Fatwa comes from the Arabic word alifta', al-fatwa simply means giving a decision. Fatwa is not an easy or baseless legal decision.

According to Ibn Taimiyah, the fatwa in its essence is not related to anything (the fatwa does not recognize the package system or sponsors) except only based on the sharia nash (Qur'an and Hadith) also fiqh and ushul fiqh principles. In general, salaf scholars must not overreact in fatwas, but cautiously salaf scholars often state that they do not know about the problems that occur. This is an expression of a salaf scholars about something that they did not surely understand. (Dahlan, 1997: 117)

In general, scholars now do not have sufficient capacity to issue fatwas individually, because they still require the involvement of scholars from various field of science that are not possible for someone who is an expert only in their field, so that to issue a fatwa at the current time is done by using ijtihad jama'i (collective ijtihad) as it has been done by scholars in Islamic social organizations so far. They carry out ijtihad together as a representation of Islamic jurists along with experts in certain fields so that the 
level of precision can be accounted for. According to Mukhtar Yahya and Fathurrahman, the results of ijtihad jama'i are not the same as ijma', because the nature of ulama involvement in ijtihad and ijma' is different. Ijtihâd jama'i may be carried out several times in different era and places, so the legal decisions are very likely to be different. But on the contrary, ijma' does not provide an opportunity of dispute because all ulama involved must have found a certain legal agreement on the matter. (Fathurrahman, 1997: 40)

\section{National Sharia Council-Indonesian Ulema Council (DSN-MUI)}

National Sharia Council - Indonesian Ulema Council (DSN-MUI) is formed in the framework of; a) to manifest Muslims aspirations regarding economic issues and encouraging the application of Islamic teachings in the field of economy / finance which are carried out in accordance with the guidelines of Islamic law, b) The establishment of the DSN-MUI aims to make the coordination of scholars in responding economic / financial issues became more efficient. Various problems / cases that require a fatwa will be accommodated and discussed together in order to get the same view by each Sharia Supervisory Board (DPS) in islamic financial institutions, c) To encourage the application of Islamic teachings in economic and financial life, the DSN-MUI will always be there and play a proactive role in responding to the dynamic development of Indonesian society in the economic and financial fields. (Muhtar, 1997: 40)

The Indonesian Ulema Council (MUI) has an important role in the development of the shari'ah economy. In this context the MUI has three related institutions, namely the National Syari'ah
Council (DSN), the Shari'ah Supervisory Board (DPS), and the Syari'ah National Arbitration (Basyarnas). Guidelines for sharia economic activities are based on the DSN fatwa. The economic activities carried out by sharia financial institutions are supervised by DPS, and sharia economic disputes are settled in Basyarnas. MUI has three related institutions in order to develop the Shari'ah economy. Namely DSN, DPS, and Basyarnas and each has their own duties and roles to complement each other. (Suardi \& Candra, 2016: 424)

Along with the increasing demand for Islamic financial services, Sharia Supervisory Board (DPS) plays an important role in the development of procedure and new products, to improve adaptability of Islamic Financial Institutions into financial industry trends and consumer expectations. Sharia Councils must be involved primarily to ensure the alignment of procedures and products with Shari'ah principles.

Syari'ah supervision can be seen as an examination of the application of religious values and Islamic ethics in the financial industry. Transitions in Shari'ah finance include a variety of technical and complex matters. A balance must be maintained so that it can provide adequate returns and at the same time remain within the boundaries of the Qur'an and Sunnah which cannot be carried out without the supervision of the quality of the shari'ah. (Rasu, 2014: 307)

Law in sharia economics is classified as a dynamic law (mutaghayyirat), so that it will be transformed according to the changes in its 'illah. Therefore, the law in the field of Islamic economics is a vast land to carry out ijtihad, because of its rapid development and it has not been discussed by the previous scholars, and 
also, the lack of the opinion from the contemporary jurists on this issue.

According to Ma'ruf Amin, in this context, the fatwa as one of the instruments for the formulation of sharia economic law has a strategic position in the operation of Islamic Financial Institutions (LKS) and Sharia Business Institutions (LBS). The fatwa in sharia economics can legitimize the products and contracts used in LKS and LBS, in which while running the operation, besides it is in line with business principles, it must also be in line with and in accordance with sharia principles. (Amin, 2017: 15)

The fatwa issued by the DSN-MUI is a fatwa on shari'ah economy which includes products, contracts, and services carried out in LKS and LBS. The fatwa was issued by the DSN-MUI because; first, it responds to the ideas of regulators (such as BI, Ministry of Finance, Financial Services Authority (OJK), etc.), which are usually intended to encourage business growth or prudence in LKS and LBS. Second, to respond to the idea of business actors in LKS and LBS. It is usually to meet market demand in the form of products and contracts. Third, to respond to the idea of the Sharia Supervisory Board (DPS). It is usually to specify the implementation of existing DSN-MUI fatwas. And fourth, to respond to the ideas from the DSN-MUI itself. It is usually refers to the opinion of the ulama contained in the figh books which are mu'tabarah, then offered to the perpetrators. (Amin, 2017: 15)

\section{Transformation of DSN-MUI Fatwa into National Law}

Constitutionally, the basis of sharia economic law rests on Pancasila as the basis of the State and Article 29 paragraph (1) of the 1945 Constitution which reads,
"The State is based on the One Godhead, and (2) The State guarantees the independence of each resident to embrace their religion and to worship according to his religion and belief." The formal legal provisions governing the implementation of sharia economic activities in Indonesia are all provisions that have gone through the process of positivisation by the State.

Shari'ah economic system (Gayo, 2011: 2) has legal legitimacy and legal certainty in the formal sector, especially in the field of Islamic banking. This juridical perspective implies that the institutionalization of shari'ah principles is a form of concretization of the transformation process of Islamic legal subsystems into an integral part of the national positive legal system and it becomes a set of rules that exclusively regulated the operational system of banking business activities, which in turn strengthened the Islamic legal authority in the Shari'ah operational concept and economic subsystem. In this sense, the existence and authority of Islamic law has been legally and formally regulated in the legal order of banking business activities and even in economic business activities.

Bismar Nasution states that the application or adoption of the Islamic economy into national law must be seen in a broad framework. For the success of the transition a sharia economic legal system must be formed in Indonesia, and it is necessary to think about integrating the principles of Islamic law into the legal system in Indonesia.

According to Lawrence Friedman, there are three elements in a legal system, namely, legal substance, legal structure, and legal culture. Therefore the first thing that must be formed in a legal system is a strong legal substance. In the sharia economics, the substance here is the 
The Uryenency of Fatw a in the Law of Sharia Piconomics in Intonesia || 205

integration of the principles of Islamic law into national regulations in Indonesia, either in the form of regulatory amendments or making special regulations governing the implementation of sharia principles in the Indonesian economy.

The second element, which must exist in a legal system is a complete and strong structure or device for implementing regulations. The existence of a religious court as an institution to resolve sharia economic disputes is a form of the Indonesian government's commitment in developing the Indonesian economy.

The last element that must exist in a legal system is a good legal culture so that the two elements above can work well in its implementation. The level of public trust in the religious court is very significant for the effectiveness and efficiency of law enforcement in the Islamic economy.

The three elements above according to the author, are things that really need to be planned carefully and continue to be strengthened in shaping a new flow of economy in Indonesia. A strong and comprehensive set of rules can also develop Islamic economics and simultaneously increase public trust, because since the sharia financial institutions were established, it was hoped that not only based on opportunities that emerged, but also based on the desire to realize an economic system that was in accordance with the principles of sharia. Judicial power holders in the Religious court must always be professional in the field of sharia economy given the growing development of modern financial transactions, and including agreements in other sharia business fields. Nowadays, there are 415 sharia economic cases that have been decided, this shows the increasing number of problems faced in sharia financial institutions. Professionalism in the form of readiness and skills of PA judges is an absolute requirement to gain public trust, especially in terms of resolving sharia economic disputes.

Islamic law that has been transformed into constitutions, is categorized into written law or positive law that applies (ius constitutum). While Islamic law that has not been transformed is categorized as an unwritten law or Ius constituendum, namely the law that should apply. Ius constituendum which has become a judge's decision is categorized as a positive law (ius constitutum) which is binding the parties in certain case. (Arto, 2017: 19)

Islamic law, before being absorbed into state law in the form of legislation, is a law that applies non-formally. The existence of Islamic law as a non-formal law can be used as the main reference in the development of formal law in Indonesia. When other legal systems experience limited concepts, Islamic law through its legal products (fiqh or fatwa) already contains provisions regarding humans as individuals and humans as social beings. At this point the position and role of MUI is very strategic, because the fatwa is one model among several models of Islamic law. Fatwas are always dynamic and adaptive to respond the problems of human and humanity. In the context of the role of fatwa, the MUI becomes the foremost pioneer in producing responsive fatwas in accordance with the demands and conditions of the Indonesian Muslim community today, not just as fatwas as mere normative dogmas halal-haram whose nature and substance repeat what 
has been in the books of the 13th and 14th centuries. However, the MUI fatwa responds to the needs of the Indonesian Muslim community from various spheres of life and society, one of which is the fatwa on sharia economic law.

Islamic economics can be stated as one of the most important fields in maintaining harmonious relations between religion and the state. (Amin, 2017: 57) Religion supports the establishment and development of Islamic economics and the state also participated in issuing policies that support the development of Islamic economics in Indonesia. Regarding the theory of relations between religion and state, the concept of Indonesian Islamic economics shows the integration of religion and state. This conclusion can be seen from the role of scholars who are increasingly recognized in Islamic economic policy instruments. The Indonesian Ulema Council as a social organization is the only social entity that is recognized and explicitly referred to in constitution.

The binding power of the fatwa is shifting. Theoretically, the fatwa has a non-binding legal power, but in de jure and de facto fatwa has binding legal power. Based on the results of research produced by the National Law Development Agency from Ministry of Law and Human Rights, that the DSNMUI legal fatwa has binding legal powers for sharia economic actors both directly and indirectly. The fatwa issued by the DSN-MUI is binding on Islamic financial institutions, despite its binding through the process of authorization provided by Bank Indonesia or the government. Fatwa becomes the basis of Bank Indonesia regulations, Ministry of Finance, Capital Market and the Financial Services
Authority (OJK) or other regulatory institutions. (Abdalloh, 2018: 16)

DSN-MUI has issued 141 fatwas related to the sharia finance industry, sharia business, and sharia economy. Fatwas regarding sharia economy have been partially absorbed into national laws, regulations of Bank Indonesia, regulations of the Financial Services Authority (OJK), and Ministerial decrees. This proves that sharia economic law after reformation era is indeed more dynamic than other sharia legal fields. Islamic economics is the most important fields in maintaining harmonious relations between religion and state. It is because the state also supports the establishment and development of the Islamic economy.

According to Ahmad Zuhdi's research (2015), it struggles regarding relations between the state and Islam in Indonesia, that the DSN fatwas are the basis for the creation of various standard guidelines for implementation in the field of Islamic economics, representing the view that positivisation of Islamic law in the realm of private law is easier to accept than public law. In this domain, ulama and umara (government/state) can work together functionally well for the benefit of the people. The government accommodates the aspirations of the DSNMUI through its fatwas to be part of the dynamics of the national economy. Besides, the DSN-MUI formulated its fatwas to meet the needs and legitimacy of the law (syari'ah) needed by the community and government/state. This relationship is increasingly important when it is felt that there is a legal vacuum in the field of Islamic economics, while the practices of the law have lived in the midst of the community as the living law and even have become a world trend. This condition shows that the positive law that 
exists is not enough to cover the need for sharia economic regulation, so it is necessary to take Islamic law as a partner which is often seen only as an desired law (ius constituendum).

Also in the institutional realm, the presence of the National Sharia Council (DSN) and the Sharia Arbitration Board (Basyarnas) is a progress in national legal politics. Both institutions are under the authority of MUI. In the constitutional structure, MUI is not part of the official power of the state. MUI is more appropriately referred to as an ordinary legal entity. It is in line with various other religious organizations. The presence of DSN and BASYARNAS in the structure of national law is in line with the enactment of Constitutional Law Number 21 of 2008 concerning Islamic Banking. The law demands the presence of institutions for the establishment of legislation and supervisors of fatwas in the field of Islamic economics carried out by DSNMUI, also an institution for alternative dispute resolution. BASYARNAS institution is intended as a way to resolve alternative disputes besides the Religious Courts. In the regulatory aspect, various laws have been issued such as Law No.21 of 2008 concerning Sharia Banking, Law Number 19 of 2008 concerning Sharia Securities, Law 23 of 2011 concerning Management of Zakat, Law No.7 of 1989 as amended by Law Number 3 Year 2006 and Law Number 50 of 2009 concerning Religious Courts, Law 41 of 2004 concerning Endowments and various other legislative provisions.

\section{CONCLUSION}

Fatwas of the DSN-MUI has become a very strategic part of sharia financial development as a new flow of the
Indonesian economy, because the DSNMUI fatwas can legitimize sharia financial contracts and products in Indonesia. Transformation of the DSN-MUI fatwas into national legal system shows that Islamic law in private field is indeed more easily accepted and more dynamic than other Islamic legal fields.

\section{REFERENCES}

Abdalloh, I. (2018). The National Shariah Board: Key to Islamic Capital Market Development in Indonesia. Islamic Finance news, Monday, 07 May 2018, Volume 15. Issue 19.

Amin, M. (2017). Solusi Hukum Islam (Makharij Fiqhiyyah) sebagai Pendorong Arus Baru Ekonomi Syariah di Indonesia (Kontribusi Fatwa DSN-MUI dalam Peraturan Perundang-undangan RI). Kementerian Agama Universitas Islam Negeri Maulana Malik Ibrahim Malang

Arto, H. A. M. (2017). Penemuan Hukum Islam demi mewujudkan Keadilan. Yogyakarta: Pustaka pelajar.

Gayo, A. A. (2011). Laporan Akhir Penelitian Hukum tentang Kedudukan Fatwa Mui dalam Upaya Mendorong Pelaksanaan Ekonomi Syariah. Jakarta: Badan Pembinaan Hukum Nasional Kementerian Hukum dan HAM RI.

https:/ / bismarnasution.com/hukumekonomi-syariah-dalam-regulasinasional/, accessed on November, $21^{\text {st }} 2018$

https:/ / dsnmui.or.id/kami/sekilas https:/ / mui.or.id/berita/dsn-muisosialisasikan-13-fatwa-terbaru/ https:/ / putusan.mahkamahagung.go.id/ direktori/perdata-agama,

Jonathan Lawrence, Islamic Finance in Indonesia: Past, Present and Future 


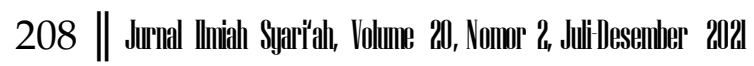

Mudzhar, M. A. \& Maksum M. (2017). Fikih Responsif Dinamika Integrasi Ilmu Hukum, Hukum Ekonomi dan Hukum Keluarga. Yogyakarta: Pustaka Pelajar.

Rasul, B. (2014). Indentifying teh Main Regulatory Chalengges for Islamic Finance, Islamic Finance; $\mathrm{g}$ and Market. dalam Andri Sumitra, Masa Depan Pasar Modal Syari'ah Indonesia. Jakarta: Prenada Media.

Suardi, A. \& Candra, M. (2016). Politik Hukum Perspektif Hukum Perdata dan pidana Islam serta Ekonomi Syariah. Jakarta: Kencana Prenada Media.

Zuhdi, A. (2015). Positivisasi Fatwa Dewan Syari'ah Nasional-Majelis Ulama Indonesia (DSN-MUI) Dalam Sistem Hukum Indonesia. Disertasi. Yogyakarta: Universitas Gadjah Mada. 